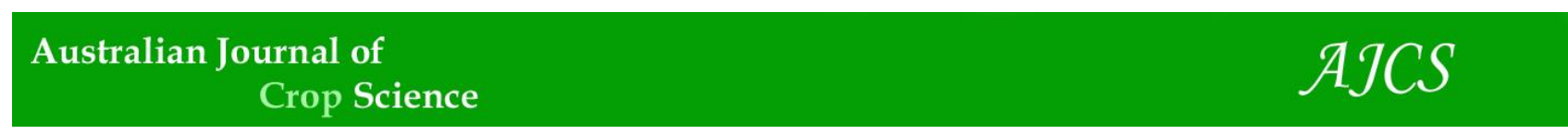

AJCS 12(06):886-891 (2018)

ISSN:1835-2707

doi: 10.21475 /ajcs.18.12.06.PNE840

\title{
Correlations between agronomic traits in papaya tree (Carica papaya L.) grown under subtropical climate of Brazil
}

\author{
Marcelo de Souza Silva, Sarita Leonel, Jackson Mirellys Azevêdo Souza, Rafael Bibiano Ferreira, Ana \\ Carolina Batista Bolfarini, Marcelo Almeida de Oliveira Júnior
}

Department of Horticulture, Universidade Estadual Paulista (UNESP), Botucatu, Brazil

*Corresponding author: mace-lo-souza@hotmail.com

\begin{abstract}
The current study aimed at evaluating the correlations between agronomic traits in papaya trees grown under Brazilian subtropical climate. A randomized block design with three treatments (Sunrise Solo, Tainung no1 and Local variety) was used. The experiment was laid out in seven blocks and five plants per plot. The following traits were assessed: plant height; insertion height of the first fruits; stem diameter; male, female, and hermaphrodite plants percentage; fruit number per plant; production; yield; percentage of normal fruits; carpelloid and pentandric fruits percentage; internal cavity diameter; fruit matter; pulp and seed yield; seeds number; soluble solids; titratable acidity; ratio and technological index. Results indicated that seed performance can be used as indirect selection criteria for genetic improvement of Sunrise Solo seeds (correlation between SP and FNP, PRO, YIELD and PNF of $0.97,0.96,0.96,-0.89$, respectively). Carpelloid fruits exhibited a positive correlation with production traits, but negative correlation with physicochemical traits in papaya fruits. Moreover, there is a modest correlation between physicochemical and productive traits of Tainung no1 and Local Variety fruits.
\end{abstract}

Keywords: genetic improvement; Carica papaya L.; variety performance.

Abbreviations: PH_Plant height; SD_Stem diameter; IHFF_Intersection height of the first fruits; FFP_Female flowers percentage; MFP_Male flowers percentage; HFP_hermaphroditic flower percentage; FNP_Fruits number per plant; PRO_Production; YIELD_Yield; PNF_Percentage normal fruits; PFP_Pentandric fruit percentage; and CFP_Carpeloids fruit percentage; FM_Fruit matter; ICD_Internal cavity diameter; PP_Pulp performance; SN_Seeds number; SP_Seed performance; SS_Soluble solids; TA_Titratable acidity; TI_Technological index.

\section{Introduction}

Carica papaya is the only representative species within the genus Carica; being widely distributed in tropical Central and South America; having a great commercial viability (Pesqueira and Farfán, 2016). Also, Brazil is a key producer of papaya in the international market, with a production of 1.6 million tons, that is, $16.7 \%$ of world production (FAO, 2016). Currently, the state of Bahia is the largest national producer (718.7 thousand tons), followed by Espirito Santo (404.7 thousand tons) and Minas Gerais (126.8 thousand tons), they all led to $80 \%$ of national production (IBGE, 2016).

Moreover, the state of São Paulo is known to concentrate small-scale producers, which held $0.7 \%$ of national production, that is, 11.8 thousand tons (IBGE, 2016). São Paulo has a very receptive market for papaya fruits, besides improving the income of small-scale producers.

Despite positive economic outlook, there are some obstacles to grow papaya all over Brazil, such as diseases and small numbers of varieties available for planting that meet both domestic and foreign markets demands.

'Solo' and 'Formosa' are commonly grown in Brazil. 'Solo' genotypes target export markets, as they present red color and small size (300-650g), while those of Formosa group have red-orange pulp and average size (1000-1300g);
Formosa group is mainly composed by commercial hybrids, besides that may include some lineages (Dias et al., 2011). The reduced number of varieties available for planting may lead to greater vulnerability to diseases, pests and edaphoclimatic variations; therefore, compromising crop sustainability due to the high genetic variability.

The relationship between phenological and production traits are crucial in selecting cultivars (Cruz et al., 2014). A selection on correlated characters is of great importance for plant breeders, since they are the result of either genetic linkage or pleiotropism. Furthermore, environment can be responsible for correlations when both traits are influenced in the same way by differences in environmental conditions (Cardoso et al., 2009).

A positive correlation exists when both variables is benefited from or harmed by the same causes of environmental effects; and a negative correlation is a relationship between two variables in which one variable increases as the other decreases and vice-versa (Nogueira et al., 2012). The magnitude of the correlation coefficient indicates the strength of such association; wherefore evaluating the influence of one variable over another in plant breeding programs (Silva et al., 2016). 
Despite the importance, there is a paucity of literature on this problem. To this end, this research aimed at evaluating the correlations between agronomic traits in papaya trees grown under Brazilian subtropical climate.

\section{Results and discussion}

\section{Sunrise Solo variety}

We have observed a significant positive correlation between $\mathrm{PH}$ and the following traits: SD (0.84), IHFFr (0.77), PRO (0.89), YIELD (0.89), FNP (0.90), CFP (0.81) and SEEDY (0.81). However, it was also observed a negative correlation between PH with PNF (-0.77) and ICD (-0.96) (Table 1). By studying phenotypic correlations of papaya accessions, Silva et al. (2016) found similar results, showing how important is to identify traits that are phenotypically correlated, since they provide a practical value on selecting individuals due to the highly expressed genes in phenotypes. Espósito et al. (2012) and Silva et al. (2014) also highlighted the importance of correlating agronomic traits, since phenotype is generally the first criterion used when selecting individuals.

We have also observed a significant positive correlation between SD and production traits, such as FNP (0.76), PRO (0.76), YIELD (0.76) and CFP (0.81); while a negative correlation was observed in ICD (-0.78) and SD (Table 1). With regards to correlation coefficients, magnitude, direction and significance must be considered. Therefore, a positive correlation is when both variables move in tandem; however, a negative correlation is defined when one variable increases, while other decreases (Nogueira et al., 2012).

Moreover, plants that present higher SD will also have higher FNP, PRO, YIELD and CPF, but lower ICD. Such behavior was also observed by Silva et al. (2007), suggesting that selecting plants with larger stem diameter may improve yield due to high genetic correlation between those traits. Ferreira et al. (2012) evaluated correlations between morphoagronomic traits of different papaya accessions; stating that the increase in fruit matter and fruit numbers are correlated with higher stem diameter. It was observed a significant positive correlations between IHFFr and the following traits: FNP (0.94), PRO (0.94), YIELD (0.94), PNF ($0.86)$, PFP (0.76), CFP (0.84), SN (0.97) and SEEDY (0.98) (Table 1). In a positive correlation, an increase or decrease in one variable always predict the same directional change for the second variable (Nogueira et al., 2012). Therefore, higher IHFFr led to lower PNF, but higher PFP and CFP; which is an important behavior due to the development of deformed fruits, such as carpelloid and pentandric.

With regards to plants sex, it was observed that HFP showed a negative correlation with FFP (-0.99), but positive with MFP (0.93); while FFP correlated negatively with MFP (0.93) (Table 1). A similar behavior was observed between correlation coefficients for FNP, PRO and YIELD, with regards to magnitude, direction and significance (Table 1). Thus, PFP, CFP, SN increased; SEEDY also increased; but PFN and ICD decreased.

All correlations were significant in Sunrise Solo variety, but a negative correlation was observed between PNF and the other variables. The increase in the percentage of normal fruits causes a decrease in other traits (Table 1). The same behavior was observed by Oliveira et al. (2010), who reported that these traits are not recommended for plant breeding programs via direct selection, i.e. increasing the number of commercial fruits per plant.

With regards to physical attributes of Sunrise Solo, a high correlation was observed between SN and SEEDY, as well as most evaluated variables (Table 1 ). Results indicated a tremendous genetic potential in seeds, which could be used as a subsidy for breeding programs that aim at parental selection to obtain superior genotypes. Regarding to the physicochemical attributes, a significant positive correlation was only observed between SS and TI (0.77); while TA, ratio (SS/TA) and TI were poorly correlated with other traits (Table 1).

\section{Tainung no1 hybrid}

We have observed a significant correlation between $\mathrm{PH}$ and three variables, that is, SD (0.82), HFP (0.80) and FFP (0.80) (Table 2). There was no significant effect between SD and other traits (Table 2). Such parameter has been used as a criterion for selecting individuals in breeding programs. Furthermore, it is important to consider plants that presented higher diameters were directly correlated with more productive individuals in this research, due to the high genetic correlation between those traits (Silva et al., 2007; Ferreira et al., 2012)

Oliveira and Dantas (2011) reported that the low insertion height of the first papaya fruits is correlated with precocity and higher yield per plant. Based on the correlation coefficients obtained in this research for IHFFr, there was no significant effect between IHFFr and PRO in Tainung №1 hybrid (Table 2). Regarding to the plant sex, there was a significant, but indirect effect between HFP and FFP (-0.99) (Table 2). Significant positive correlations were found between FNP and PRO (0.99), as well as YIELD (0.96), while physicochemical parameters of SS (-0.84), TA $(-0.80)$ and TI ($0.95)$ correlated indirectly, that is, the number of fruits per plant increased, while physicochemical values decreased (Table 2). The decrease in physicochemical content associated with the increase in FNP is probably due to the source-drain fluctuations that occur along the cycle (Saran et al., 2015), besides crop management; edaphic and climatic conditions that could affect sugar and acidity levels in papayas. These results were like those presented by Queiroga et al. (2008), with melon, and by Oliveira et al. (2010), with papaya, in which the large number of fruits resulted in a decrease in soluble solids content.

A negative correlation was observed between PNF and CFP $(-0.85)$, whereas a positive correlation was observed between PNF and SS (0.97), as well as TI (0.86) (Table 2). Despite PNF, there was a significant negative correlation between CFP and SS (-0.88), AT (-0.79), as well as TI (-0.92), that is, the percentage of carpelloids increased among papayas fruits, while soluble solids, titratable acidity and technological index decreased (Table 2).

There was null effect between FM and all evaluated traits (Table 2). Thus, correlation studies are responsible for indicating the inheritable fraction from parent to their progeny. Then, if two characters present correlation, it is possible to obtain gains for one of them through indirect selection (Coimbra et al., 2000); however, if there is no significant correlation between two traits, it is not recommended as a selection criterion (Cruz et al., 2014). 
Table 1. Correlation coefficients among agronomic traits in Sunrise Solo cultivar. Botucatu, São Paulo State, Brazil, 2017.

\begin{tabular}{|c|c|c|c|c|c|c|c|c|c|c|c|c|c|c|c|c|c|c|c|}
\hline & SD & IDFF & HFP & FFP & FNP & PRO & PROD & PNF & PFP & CPF & FM & ICD & PP & NS & SP & SS & TA & RATIO & TI \\
\hline I & $0.84^{*}$ & $0.77^{\circ}$ & -0.15 & 0.15 & $0.90^{* *}$ & $0.89^{* *}$ & $0.89^{* *}$ & $-0.77^{*}$ & 0.52 & $0.81^{*}$ & -0.44 & $-0.96 "$ & -0.60 & 0.66 & $0.81^{*}$ & $\begin{array}{l}-0.02 \\
\end{array}$ & -0.45 & 0.24 & -0.70 \\
\hline ) & & 0.56 & -0.49 & 0.49 & $0.76^{*}$ & $0.76^{*}$ & $0.76^{*}$ & -0.71 & 0.34 & $0.80^{*}$ & -0.72 & $-0.78^{*}$ & -0.54 & 0.47 & 0.67 & -0.26 & -0.39 & 0.13 & -0.72 \\
\hline $\mathrm{FF}$ & & & 0.23 & -0.23 & $0.94^{* *}$ & $0.94^{* *}$ & $0.94^{* *}$ & $-0.86^{*}$ & $0.76^{*}$ & $0.84^{*}$ & -0.11 & -0.71 & -0.44 & $0.97^{* *}$ & $0.98^{* *}$ & -0.12 & -0.40 & 0.11 & -0.45 \\
\hline :P & & & & $-0.99^{* *}$ & 0.05 & 0.10 & 0.10 & -0.15 & 0.61 & -0.03 & $0.93^{* *}$ & 0.26 & 0.49 & 0.20 & 0.06 & 0.04 & 0.54 & -0.46 & 0.59 \\
\hline P & & & & & -0.05 & 0.10 & -0.10 & 0.15 & -0.61 & 0.03 & $-0.93^{* *}$ & -0.26 & -0.49 & -0.20 & -0.06 & -0.04 & -0.54 & 0.46 & -0.59 \\
\hline JP & & & & & & $0.96^{* *}$ & $0.96^{* *}$ & $-0.95^{* *}$ & $0.76^{*}$ & $0.96^{* *}$ & -0.27 & $-0.80^{*}$ & -0.41 & $0.90^{* *}$ & $0.97^{* *}$ & -0.29 & -0.33 & 0.01 & -0.56 \\
\hline २० & & & & & & & $0.99^{* *}$ & $-0.96^{* *}$ & $0.79^{*}$ & $0.96^{* *}$ & -0.23 & $-0.79^{*}$ & -0.37 & $0.89^{* *}$ & $0.96^{* *}$ & -0.29 & -0.29 & -0.03 & 0.52 \\
\hline ELD & & & & & & & & $-0.96^{*}$ & $0.79^{*}$ & $0.96^{*}$ & -0.23 & $-0.79^{*}$ & -0.37 & $0.89^{* *}$ & $0.96^{* *}$ & -0.29 & -0.29 & -0.03 & 0.52 \\
\hline JF & & & & & & & & & $-0.87^{*}$ & $-0.98^{* *}$ & 0.12 & 0.60 & 0.13 & $-0.85^{*}$ & $-0.89^{* *}$ & 0.52 & 0.06 & 0.30 & 0.33 \\
\hline :P & & & & & & & & & & $0.76^{*}$ & 0.37 & -0.31 & 0.18 & 0.73 & 0.70 & -0.43 & 0.28 & -0.52 & 0.07 \\
\hline :P & & & & & & & & & & & -0.30 & -0.67 & -0.24 & $0.84^{*}$ & $0.90^{* *}$ & -0.53 & -0.19 & -0.19 & -0.45 \\
\hline 1 & & & & & & & & & & & & 0.55 & 0.71 & -0.10 & -0.28 & -0.01 & 0.72 & -0.56 & $0.82^{*}$ \\
\hline $\mathrm{F}$ & & & & & & & & & & & & & $0.77^{*}$ & -0.59 & $-0.76^{*}$ & -0.19 & 0.64 & -0.49 & $0.82^{*}$ \\
\hline , & & & & & & & & & & & & & & -0.34 & -0.48 & -0.56 & $0.93^{* *}$ & $-0.89^{* *}$ & $0.96^{* *}$ \\
\hline J & & & & & & & & & & & & & & & $0.97^{* *}$ & -0.27 & -0.39 & 0.03 & -0.47 \\
\hline , & & & & & & & & & & & & & & & & -0.21 & -0.47 & 0.12 & -0.62 \\
\hline & & & & & & & & & & & & & & & & & -0.24 & -0.44 & $0.77^{*}$ \\
\hline$t$ & & & & & & & & & & & & & & & & & & $-0.90^{* *}$ & $0.91^{* *}$ \\
\hline ITIO & & & & & & & & & & & & & & & & & & & $-0.76^{*}$ \\
\hline
\end{tabular}

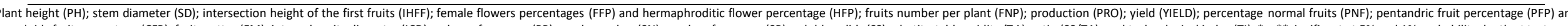

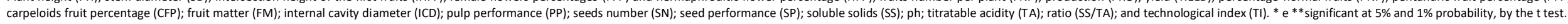

Table 2. Correlation coefficients among agronomic traits in Tainung nô1 hybrid. Botucatu, São Paulo State, Brazil, 2017.

\begin{tabular}{|c|c|c|c|c|c|c|c|c|c|c|c|c|c|c|c|c|c|c|c|}
\hline & SD & IDFF & HFP & FFP & FNP & PRO & PROD & PNF & PFP & $\mathrm{CPF}$ & $\mathrm{FM}$ & $I C D$ & $\mathrm{PP}$ & NS & $\mathrm{SP}$ & SS & TA & RATIO & $\mathrm{TI}$ \\
\hline T & $82^{*}$ & .25 & $80^{\circ}$ & $80^{\circ}$ & 44 & 39 & 39 & .10 & 26 & 21 & 61 & 11 & .58 & 38 & 31 & .10 & .04 & 34 & .31 \\
\hline ) & & .66 & 46 & .46 & 35 & 30 & 30 & 15 & .25 & 17 & 30 & 23 & .39 & .11 & 05 & 09 & .16 & 63 & .09 \\
\hline $\mathrm{FF}$ & & & .03 & 03 & 25 & 36 & 36 & .69 & 70 & 43 & .07 & .67 & .25 & $77^{*}$ & 64 & 57 & .09 & .45 & .55 \\
\hline$=p$ & & & & $.99^{* *}$ & 52 & 39 & 39 & .25 & 20 & 18 & 74 & 10 & .45 & 39 & 14 & .32 & .24 & 33 & .44 \\
\hline p & & & & & .52 & .39 & .39 & 25 & .20 & .18 & .74 & .10 & 45 & .39 & .14 & 32 & 24 & .33 & 44 \\
\hline$J P$ & & & & & & $99^{* *}$ & $96^{* *}$ & .74 & .02 & $91^{* *}$ & 05 & .65 & .73 & 43 & 61 & $.84^{* *}$ & $.80^{*}$ & 71 & $.95^{* \prime}$ \\
\hline 30 & & & & & & & $96^{* *}$ & $.85^{*}$ & 09 & $98^{* *}$ & 04 & .69 & .67 & 49 & 69 & $.88^{* *}$ & $.79^{*}$ & 61 & $.95^{* \prime}$ \\
\hline ELD & & & & & & & & $.85^{*}$ & 09 & $98^{* *}$ & 04 & .69 & .67 & 49 & 69 & $.88^{* *}$ & $.79^{*}$ & 61 & $.95^{* \prime}$ \\
\hline vF & & & & & & & & & .29 & $.86^{*}$ & .17 & 63 & 33 & .55 & .58 & $97^{* *}$ & 72 & .25 & $86^{*}$ \\
\hline :p & & & & & & & & & & 06 & 26 & .28 & .34 & $88^{* *}$ & 61 & .08 & 44 & .68 & .22 \\
\hline :p & & & & & & & & & & & .13 & $.78^{*}$ & .61 & 45 & 71 & $.88^{* *}$ & $.79^{*}$ & 55 & $.92^{\circ}$ \\
\hline$n$ & & & & & & & & & & & & 54 & 14 & 16 & .21 & .12 & .02 & .01 & .01 \\
\hline $\mathrm{F}$ & & & & & & & & & & & & & 69 & .61 & $.85^{*}$ & 63 & 39 & .12 & $79^{\circ}$ \\
\hline ; & & & & & & & & & & & & & & .68 & $.83^{*}$ & 37 & 19 & .32 & 73 \\
\hline J & & & & & & & & & & & & & & & $86^{*}$ & .43 & 06 & .31 & .63 \\
\hline , & & & & & & & & & & & & & & & & .50 & .15 & .02 & .75 \\
\hline & & & & & & & & & & & & & & & & & .50 & $84^{*}$ & .43 \\
\hline$t$ & & & & & & & & & & & & & & & & & & $80^{*}$ & 71 \\
\hline ATIO & & & & & & & & & & & & & & & & & & & .45 \\
\hline
\end{tabular}

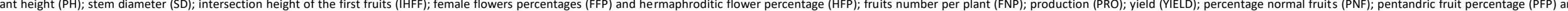
carpeloids fruit percentage (CFP); fruit matter (FM); internal cavity diameter (IID); pulp performance (PP); seeds number (SN); seed performance (SP); soluble solids (SS); ph; titratable acidity (TA); ratio (SS/TA); and technological index (TI). * ${ }^{* *}$ *significant at $5 \%$ and $1 \%$ probability, by the t test. 
Table 3. Correlation coefficients among agronomic traits in Local variety. Botucatu, São Paulo State, Brazil, 2017.

\begin{tabular}{|c|c|c|c|c|c|c|c|c|c|c|c|c|c|c|c|c|c|c|c|}
\hline & SD & IHFF & $\mathrm{FP}$ & MFP & $\mathrm{JP}$ & 20 & PROD & PNF & PFP & $\mathrm{CPF}$ & $\mathrm{FM}$ & ICD & PP & NS & SP & $S$ & TA & RATIO & $\mathrm{TI}$ \\
\hline$\overline{\mathrm{H}}$ & $0.82^{*}$ & -0.25 & $.80^{*}$ & $-0.80^{*}$ & 39 & .09 & 0.39 & 0.44 & 0.26 & 0.21 & 0.61 & 0.11 & -0.58 & 0.38 & 0.31 & 3.08 & -0.04 & 0.34 & -0.31 \\
\hline D & & -0.66 & .46 & -0.46 & 30 & 14 & 0.30 & 0.35 & -0.25 & 0.17 & 0.30 & 0.23 & -0.39 & -0.12 & 0.05 & .09 & -0.16 & 0.63 & -0.08 \\
\hline $\mathrm{HFF}$ & & & 0.03 & 0.03 & 36 & .69 & 0.36 & 0.25 & 0.70 & 0.43 & -0.07 & -0.67 & -0.25 & $0.77^{*}$ & 0.64 & 0.57 & -0.09 & -0.45 & -0.55 \\
\hline FP & & & & $-0.99^{* *}$ & 39 & .25 & 0.39 & 0.52 & 0.20 & 0.18 & 0.74 & 0.10 & -0.45 & 0.39 & 0.14 & 0.32 & -0.04 & -0.24 & 0.33 \\
\hline AFP & & & & & .39 & 25 & -0.39 & -0.51 & -0.20 & -0.18 & -0.74 & -0.10 & 0.45 & -0.39 & -0.14 & .32 & 0.04 & 0.24 & 0.33 \\
\hline NP & & & & & & .44 & -0.44 & -0.74 & -0.02 & $0.91^{* *}$ & 0.05 & -0.59 & 0.14 & -0.73 & 0.43 & $.84^{* *}$ & $-0.80^{*}$ & 0.71 & $-0.95^{* *}$ \\
\hline 'RO & & & & & & & $0.99^{* *}$ & $0.96^{* *}$ & 0.09 & $0.98^{* *}$ & 0.04 & -0.69 & -0.67 & 0.49 & 0.69 & $3.88^{* *}$ & $-0.79^{*}$ & 0.60 & $-0.95^{* *}$ \\
\hline IEL & & & & & & & & $0.96^{* *}$ & 0.09 & $0.98^{* *}$ & 0.04 & -0.69 & -0.67 & 0.49 & 0.69 & J.88** & $-0.79^{*}$ & 0.60 & $-0.95^{* *}$ \\
\hline NF & & & & & & & & & -0.29 & $-0.86^{*}$ & -0.17 & -0.45 & 0.36 & 0.33 & -0.55 & $.96^{* *}$ & -0.45 & 0.72 & -0.25 \\
\hline 'FP & & & & & & & & & & 0.06 & 0.26 & -0.28 & -0.34 & $0.88^{* *}$ & 0.63 & 0.08 & 0.44 & -0.68 & -0.22 \\
\hline :FP & & & & & & & & & & & -0.13 & $-0.78^{*}$ & -0.61 & 0.45 & 0.71 & $J .88^{* *}$ & $-0.79^{*}$ & 0.55 & $-0.92^{* *}$ \\
\hline$M$ & & & & & & & & & & & & 0.54 & 0.14 & 0.16 & -0.21 & 0.12 & -0.03 & -0.01 & -0.01 \\
\hline IF & & & & & & & & & & & & & 0.69 & -0.61 & $-0.85^{*}$ & .63 & 0.39 & -0.14 & $0.79^{*}$ \\
\hline 'P & & & & & & & & & & & & & & -0.68 & $-0.83^{*}$ & .37 & 0.19 & -0.32 & 0.73 \\
\hline $\mathrm{N}$ & & & & & & & & & & & & & & & $0.86^{*}$ & 0.43 & -0.01 & -0.31 & -0.63 \\
\hline$P$ & & & & & & & & & & & & & & & & 0.49 & -0.14 & -0.02 & -0.75 \\
\hline$S$ & & & & & & & & & & & & & & & & & $0.84^{*}$ & -0.45 & $0.90^{* *}$ \\
\hline A & & & & & & & & & & & & & & & & & & $-0.79^{*}$ & 0.71 \\
\hline :ATI & & & & & & & & & & & & & & & & & & & 0.52 \\
\hline
\end{tabular}

Plant height (PH); stem diameter (SD); intersection height of the first fruits (IHFF); female flowers percentages (FFP) and male flowers percentage (HFP); fruits number per plant (FNP); production (PRO); yield (YIELD); percentage normal fruits (PNF); pentandric fruit percentage (PFP) and carpeloids fruit percentage (CFP); fruit matter (FM); internal cavity diameter (ICD); pulp performance (PP); seeds number (SN); seed performance (SP); soluble solids (SS); ph; titratable acidity (TA); ratio (SS/TA); and technological index (TI). ${ }^{*} \mathrm{e}^{* *}$ significant at $5 \%$ and $1 \%$ probability, by the $t$ test.

In Tainung №1 hybrid, there was a statically significant indirect effect between ICD and PULPY, as well as SEEDY, with correlation coefficients of -0.85 and -0.83 , respectively (Table 2). Oliveira et al. (2010) also observed a significant indirect effect of different papaya accessions between ICD and PULPY; however, these authors did not observe the effect of internal cavity on seeds yield of papaya.

The physicochemical attributes of SS and TA behaved controversially when correlated with ratio (SS/AT). Furthermore, the increase in SS enhanced ratio values (SS/AT) due to their significant effect; whilst higher TA decreased ratio values (SS/AT), due to the indirect correlation (Table 2). In papaya fruits, the relationship between soluble solids and organic acids content is a parameter that determines the consumption point and acceptability of those fruits by consumers, since it reflects on sensorial quality and maturity index (Chitarra and Chitarra, 2005).

\section{Papaya Local Variety}

A modest significant correlation was observed between phenological (PH, SD, IHFFr, FFP and MFP) and production traits, physical and physicochemical quality (Table 3 ). The correlation between phenological traits is of immense importance to determine criteria for selecting individuals. However, magnitude and correlations values are not enough to clarify all studied variables, since there may be no real cause-effect relationship. Thus, a high or low correlation coefficient may be the effect of other variables, without exactly revealing the relative importance of direct and indirect effects of those factors (Cruz et al., 2014). Moreover, Local variety is a dioecious papaya genotype, which can be justified by the presence of male flowers and the absence of hermaphrodite flowers among evaluated traits (Table 3).

For production parameters, there was a significant direct effect between FNP and CFP (0.91), as well as SS (0.84), while there was an indirect correlation with TA $(-0.80)$ and TI $(-0.95)$ (Table 3). Within production, Oliveira et al. (2010) reported that the NFP has a great economic appeal, being a crucial parameter when selecting papaya genotype adapted to different production systems. There was no significant correlation between FNP and most evaluated traits. Thus, there is a great complexity of genetic and environmental factors about traits related to number of fruits per plant (Cruz et al., 2014). Therefore, this research effort was to develop methodological tools that increased FNP; focusing on direct and indirect effects of correlations in order to evaluate the effect of an independent variable on a dependent one (Oliveira et al., 2010).

For PRO and YIELD, the correlation behaved similarly among traits with a direct effect on PNF (0.96) and CFP (0.98) and indirect effect on the physicochemical traits, such as SS (-0.88), TA (-0.79) and TI (-0.95) (Table 3). Therefore, results indicated that PNF presented an indirect effect on CFP (-0.86), whereas SS (0.96) increased in normal fruits due to the significant positive correlation (Table 3 ).

The correlations between PFP and different phenological traits, productive or fruit quality were of low magnitude, with a direct effect only on SN (0.88). For CFP correlations, it was found a negative effect on fruit quality, such as ICD ($0.78)$, SS (-0.88), TA (-0.79) and TI (-0.92) (Table 3). Results indicated low fruit quality when associated with the presence of carpelelloid, whose are commercially undesirable fruits, and their development is usually associated with high soil moisture, low temperatures and excess of nitrogen in the soil, being temperature the major factor (Dias et al., 2011).

For FM, lower magnitude of the correlation coefficient indicated neither direct nor indirect effect on attributes related to fruit quality (Table 3). Previously, Souza et al. (2014) evaluated the correlation between physical and physicochemical variables in Local Variety and did not observe any effect between FM and quality traits of papaya. There was an indirect effect between ICD and PULPY, as well as SEEDY, with correlation coefficients of -0.85 and -0.83 , respectively. There was a positive correlation between SN and SEEDY (0.86) (Table 3). Oliveira et al. (2010) and Dias et al. (2011) also found higher magnitude of the correlation 
coefficient regarding seed yield per papaya fruits, whereas Souza et al. (2014) did not notice such correlation.

The ratio (SS/AT) is important to define fruit flavor, as expected it showed a higher correlation with TA $(-0.79)$ than SS (-0.45) (Table 3). Giles et al. (2016) also observed a negative correlation (-0.87) in Spondias purpurea L. between ratio (SS/AT) and acidity. Results indicated that palatable fruits will be easily selected whether it is based on acidity change. However, acidity is essential for fruits destined for industrial processing, since prevents microbial growth, besides allowing greater flexibility by adding sugar (Giles et al., 2016). For fresh market consumption, it is desirable to select cultivars towards the increase in SS/AT ratio.

Also, regarding the attributes of physicochemical quality in Local variety fruits, a significant positive correlation was found in SS (0.90) (Table 3). Being important to emphasize that technological index (TI) considers fruits physicochemical traits, whereas the ratio (SS/AT) is only related to maturity indices; therefore, $\mathrm{Tl}$ is more representative.

The technological index links pulp yield to soluble solids percentage, that is, a production yield index. Therefore, it has been widely used for commercializing fruits (mainly citrus) at different prices; such process has been used in many food industries (Chitarra and Chitarra, 2005).

\section{Materials and methods}

\section{Plant materials}

Sunrise Solo cultivar, Tainung $n^{\circ} 1$ hybrid and Local variety were chosen, as they are the most commonly grown type of papaya in Brazil. Sowing was performed 60 days before planting; besides all seedlings were kept in a black bulk cloth shade at Lageado Experimental Farm, School of Agriculture in Botucatu.

Sunrise Solo and Tainung $n^{\circ} 1$ seeds were purchased from ISLA Seeds Company, being Tainung $n^{\circ} 1$ seeds from $F_{2}$ generation. Moreover, Local variety seeds were collected from an orchard of Monte Alto Farm, located in the city of São Manuel, state of São Paulo.

\section{Location and description of the experimental area}

The experiment was carried out at the Lageado Experimental Farm, School of Agriculture (FCA/UNESP), campus of Botucatu. The area has the following geographical coordinates of $22^{\circ} 51^{\prime} 55^{\prime \prime} \mathrm{S} 48^{\circ} 26^{\prime} 22^{\prime \prime} \mathrm{W}$ at an altitude of $810 \mathrm{~m}$. The climate type is mesothermic, Cwa, that is, subtropical humid with dry winter and rainfall from November to April, with average annual precipitation of $1433 \mathrm{~mm}$; relative humidity of $71 \%$; and average annual temperature of $19.3^{\circ} \mathrm{C}$ (Cunha and Martins, 2009). Soil was classified as Red Nitosol, according to the Brazilian Soil Classification System (Embrapa, 2013).

\section{Experimental design and treatments}

Using a randomized block design, units were grouped into seven blocks of five plants each and three treatments, that is, three varieties (Sunrise Solo, Tainung no1 and Local). In March 2014, trees were planted at a spacing of $2 \times 2 \mathrm{~m}$; cultural methods were used as recommended for the crop, except for sexing.

\section{Characteristics evaluated}

From June 2014 to July 2015, the following traits were evaluated: plant height $(\mathrm{PH})$, determined from soil level to the insertion point of the youngest leaf; insertion height of the first fruits (IHFFr), determined from soil level to the insertion of the first fruit branch, using a tape measure and expressed in $\mathrm{cm}$; stem diameter (SD), determined at $10 \mathrm{~cm}$ with a pachymeter from the soil level and expressed in $\mathrm{cm}$ at three months after planting; male flowers percentages (MFP), female flowers percentages (FFP) and hermaphroditic flower percentage (HFP) were determined through plant sex identification at the beginning of flowering; number of fruits per plant (NFP) were counted during harvesting; production (PRO) was determined by weighing the harvested fruits in each plant and expressed in kg.plant ${ }^{-1}$; yield (YIELD) was determined by considering a stand of 2500 plants. ha ${ }^{-1}$ and expressed in t.ha ${ }^{-1}$; normal fruits percentage (NFP); carpeloids fruit percentage (CFP) and pentandric fruit percentage (PFP), in which each harvested fruit was individually analysed to assess the presence or absence of these abnormalities.

The following physical attributes of the fruits were measured: fruit matter (FM) weighed on an analytical balance and expressed in $\mathrm{kg}$; internal cavity diameter (ICD), measured with digital calliper and expressed in $\mathrm{cm}$; pulp performance (PP) and seed performance (SP), based on the relation between the contents of pulp and seeds by fruit matter and expressed as percentage; seeds number (SN) were counted per fruit.

The following physicochemical attributes were determined: soluble solids (SS) were measured by using a refractometer and expressed in oBrix; $\mathrm{pH}$ measurements were obtained by a digital $\mathrm{pH}$ meter; titratable acidity (TA), as described in AOAC (2016); ratio was based on the relationship between SS and TA contents; and technological index (TI) by considering SS x PY/100 (Chitarra \& Chitarra, 2005).

\section{Statistical analysis}

Data were submitted to analysis of variance. The estimates of the genotypic correlation among studied traits were obtained by using Pearson's equation (1):

$\mathrm{r}=\frac{\sum_{\mathrm{i}=1}^{\mathrm{n}}\left(\mathrm{x}_{\mathrm{i}}-\overline{\mathrm{X}}\right)\left(\mathrm{Y}_{\mathrm{I}}-\overline{\mathrm{Y}}\right)}{(\mathrm{n}-1) \mathrm{S}_{\mathrm{X}} \mathrm{S}_{\mathrm{Y}}}$

Eq. 1

Where, $\bar{X}$ and $\bar{Y}$ are the sample mean of $X$ and $Y$, respectively, while $S_{x}$ and $S_{y}$ are the standard deviations of $X$ and $Y$, respectively. Statistical analysis was performed using the software ASSISTAT (Silva and Azevedo, 2016).

\section{Conclusion}

After fruits production, a great potential was observed in seed yield that could be the best selection criteria for genetic improvement of this trait via indirect selection. Carpelloid fruits were positively correlated with production traits, but negatively with physicochemical quality parameters. However, there was a modest and direct correlation between physicochemical parameters and the other evaluated variables in papaya fruits. 


\section{Acknowledgements}

The authors would like to thank to the Coordination for the Improvement of Higher Education Personnel (CAPES) to scholarship granted for the first and fifth authors, and to National Council for Scientific and Technological Development (CNPq) to scholarship granted for the third author.

\section{References}

AOAC - Association of official analytical chemistry (2016) The official methods of analysis of the association of official analytical chemistry. 20. ed. Washington. 3172p.

Cardoso, DL, Silva, RF, Pereira, MG, Viana, AP, Araújo, EF (2009) Diversidade genética e parâmetros genéticos relacionados à qualidade fisiológica de sementes em germoplasma de mamoeiro. Rev Ceres. 56: 572-579.

Chitarra MIF, Chitarra AB (2005) Pós-colheita de frutas e hortaliças: fisiologia e Manuseio. Editora UFLA. 783p.

Coimbra, JLM, Guidolin, AF, Carvalho, FIF, Azevedo, R (2000) Correlações canônicas: II - Análise do rendimento de grãos de feijão e seus componentes. Rev Cienc Rural. 30 (1): 3135.

Cruz, CD, Regazzi AJ, Carneiro, PCS (2014) Modelos biométricos aplicados ao melhoramento genético. 3. ed. Viçosa, MG: UFV. 480p.

Cunha, AR, Martins, D (2009) Classificação climática para os municípios de Botucatu e São Manuel, SP. Irriga. 14 (1): 111.

Dias, NLP, Oliveira, EJ, Dantas, EJ (2011) Avaliação de genótipos de mamoeiro com uso de descritores agronômicos e estimação de parâmetros genéticos. Pesq Agropec Bras. 46 (11): 1471-1479.

EMBRAPA - Empresa Brasileira De Pesquisa Agropecuária (2013) Sistema brasileiro de classificação de solos. 3. ed. Rio de Janeiro: Embrapa Solos. 353p.

Espósito, DP, Peternelli, LA, Paula, TOM, Barbosa, MHP (2012) Análise de trilha usando valores fenotípicos e genotípicos para componentes do rendimento na seleção de famílias de cana-de-açúcar. Rev Cienc Rural. 42 (1): 3844.

Ferreira, JP, Schmildt, O, Schmildt, ER, Piantavinha, EC, Cattaneo, LF (2012) Correlações entre características morfo-agronômicas de acessos de mamoeiro. Encic Bios. 8 (14): 246-257.

FAO - Food and Agriculture Organization of the United Nations (2016) Faostat Database. <http://faostat.fao.org/site/339/default.aspx>. 20 Nov. 2016.

Giles, JAD, Oliari, LS, Rocha, ACB, Schmildt, ER, Silva, W, França, JM (2016) Correlações entre características físicas, químicas e físico-químicas de frutos de cirigueleira. Rev Agro@mbiente On-line. 10 (1): 30 - 35.

IBGE - Instituto Brasileiro de Geografia e Estatística (2016) Mamão: área plantada e quantidade produzida. $<$ http://www.ibge.gov.br/estadosat/perfil.php?sigla=sp > 20 Ago. 2016.

Nogueira, AP, Sediyama, T, Sousa, LB, Hamawaki, OT, Cruz, CD, Pereira, DG, Matsuo, E (2012) Análise de trilha e correlações entre caracteres em soja cultivada em duas épocas de semeadura. Biosc Journal. 28 (6): 877-888.
Oliveira, EJ, Lima, DS, Lucena, RS, Motta, TBN, Dantas, JLL (2010) Correlações genéticas e análise de trilha para número de frutos comerciais por planta em mamoeiro. Pesq Agro Bras. 45 (8): 855-862.

Pesqueira, MC, Farfán, JN (2016) Genetic diversity and structure of wild populations of Carica papayain Northern Mesoamerica inferred by nuclear microsatellites andchloroplast markers. Annals Bot. 118 (7): 1293-1306.

Queiroga, RCF, Puiatti, M, Fontes, PCR, Cecon, PR (2008) Produtividade e qualidade de frutos de meloeiro variando o número de frutos e de folhas por planta. Hort Bras. 26 (2): 209-215.

Saran, PL, Solanki, IS, Choudhary, R (2015) Papaya: Biology, Cultivation, Production and Uses. CRC press, Taylor and Francis Group, United Kingdom. 266p.

Souza, JMA, Ataíde, EM, Silva, MS (2014) Qualidade póscolheita e correlação entre características físicas e químicas de frutos de mamoeiro comercializados em Serra Talhada - PE. Magistra, 26 (4): 556-562.

Silva, FAS, Azevedo, CAV (2016) The Assistat Software Version 7.7 and its use in the analysis of experimental data. Afr J Agri Res. 11(39): 3733-3740.

Silva, FF, Pereira, GP, Ramos, HCC, Damasceno Junior, PC, Pereira, TNS, Ide, CD (2007) Genotypic correlations of morpho-agronomic traits in papaya and implications for genetic breeding. Crop Breed Appl Biotec. 7: 345-352.

Silva, AC, Morais, OM, Santos, JL, d'Arede, LO, Silva, CJ, Rocha, MM (2014) Estimativa de parâmetros genéticos em Vigna unguiculata. Rev Cienc Agr. 37 (4): 399-407.

Silva, CA, Schmildt, ER, Schmildt, O, Alexandre, RS, Cattaneo, LF, Ferreira, JP, Nascimento, AL (2016) Correlações fenotípicas e análise de trilha em caracteres morfoagronômicos de mamoeiro. Rev Agro@mbiente Online. 10(3): 217-227. 